\title{
Application of Real Time loop mediated isothermal amplification (RT LAMP) as a point of care assay using dried blood spots for rapid detection of HIV infection
}

\author{
Lavanya Vanjari ${ }^{1}$, Lakshmi Vemu ${ }^{1 *}$, Lalit Dandona ${ }^{2}$, John A Schneider ${ }^{3}$ \\ From 2nd International Science Symposium on HIV and Infectious Diseases (HIV SCIENCE 2014) \\ Chennai, India. 30 January - 1 February 2014
}

\section{Background}

Early and rapid diagnosis of HIV is essential to reduce the transmission and to start Anti Retroviral Therapy. The increasingly sophisticated molecular methods for diagnosing acute HIV infection have a direct impact on patient management as they have been developed to overcome the limitations of serological assays. Development of a further methodology, which is technologically simple and equally sensitive, accessible and affordable, is essential to detect the very few copies of viral genome during acute HIV infection. Hence in the present study a Real Time Loop Mediated Isothermal Amplification (RT LAMP) assay on Dried Blood Spots (DBS) for the detection of HIV RNA was developed for an early and specific diagnosis of HIV.

\section{Methods}

To evaluate HIV RT LAMP in comparison with real time PCR, 600 DBS samples from high risk groups (300 truck drivers and 300 Men who have sex with men) and 100 healthy and age matched individuals (control group) were included in the study. Informed consent was obtained from all the patients and controls.

\section{Results}

The performance characteristics of the HIV RT LAMP in comparison with Real Time PCRs were 100\% sensitive and specific with a \% CV less than 10.

\footnotetext{
* Correspondence: lakshmi57vemu@gmail.com

'Department of Microbiology, Nizam's Institute of Medical Science, Hyderabad, India

Full list of author information is available at the end of the article
}

\section{Conclusion}

The HIV RT LAMP on DBS, developed in this study, proved to be a highly sensitive, accurate, simple and affordable assay and easy to be performed in any small laboratory, especially in developing countries with a potential of a point of care assay, costing approximately 5 times lesser than the sophisticated molecular methods.

\section{Authors' details}

'Department of Microbiology, Nizam's Institute of Medical Science, Hyderabad, India. ${ }^{2}$ Public Health Foundation of India, New Delhi, India. ${ }^{3}$ University of Chicago, USA.

Published: 27 May 2014

doi:10.1186/1471-2334-14-S3-011

Cite this article as: Vanjari et al:: Application of Real Time loop mediated isothermal amplification (RT LAMP) as a point of care assay using dried blood spots for rapid detection of HIV infection. BMC Infectious Diseases 2014 14(Suppl 3):011.

Submit your next manuscript to BioMed Central and take full advantage of:

- Convenient online submission

- Thorough peer review

- No space constraints or color figure charges

- Immediate publication on acceptance

- Inclusion in PubMed, CAS, Scopus and Google Scholar

- Research which is freely available for redistribution

Submit your manuscript at www.biomedcentral.com/submit
() Biomed Central 